\title{
Freshman Linked Cohort Classes In The Study Of Business: A Comparative Analysis Of Performance And Completion Of The Lower Division Core
}

Mark F. Levine (E-mail: mlevine@ @ csuchico.edu), California State University Chico

Paul W. Guy (E-mail: pguy@csuchico.edu), California State University Chico

\begin{abstract}
The paper presents the results of a study designed to measure the efficacy of using cohort linked freshmen courses in preparing students for the study of business. Specifically, an experimental group of students were enrolled in three linked freshmen courses each oriented toward global business: 1) freshmen composition, 2) small group communications, and 3) introduction to global business. The control group of students was enrolled in the introduction to global business course. However, they independently enrolled in any other non-business focused freshmen courses to fill out their schedules.
\end{abstract}

\section{Introduction}

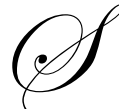

ubstantial changes in higher education have developed in the last decade as reliance on technology has increased, student demographics have become more diverse to reflect an emphasis on life-long learning and continuing education, and institutions have strove to become student centered in an era of customer focused relationships. One result of these rapid changes has been an increased awareness of the need to build learning communities to promote student learning and retention.

The formation and maintenance of learning communities helps universities provide an educational experience rich in faculty and peer support networks as well as creating an opportunity for students to fully participate in directing their own learning experience (Kellogg, 1999). "A learning community is any one of a variety of curricular structures that link together several existing courses - or actually restructure the curriculum material entirely - so that students have opportunities for deeper understanding and integration of the material they are learning, and more interaction with one another and their teachers as fellow participants in the learning enterprise" (Gabelnick, MacGregor, Matthews, \& Smith, 1990, p. 19). Kellogg (1999) identifies five major learning community models: Linked Courses, Learning Clusters, Freshmen Interest Groups, Federated Learning Communities, and Coordinated Studies. The focus of the present study will be on the efficacy of freshman linked cohort classes in the study of business at California State University Chico.

In an early study of London medical students, Abercrombie (1960) showed that successful medical students intuit the importance of feedback, assimilation, accommodation, and other social cognitive aspects of collaboration. Other research indicates students seek out experiences with peers that provide opportunities for learning goal setting, negotiation of authority, personal responsibility, persistence, inductive and deductive approaches to learning, creative and logical application of new information, and interdependence with students of different backgrounds (Horn, 1997). Linked courses allow college instructors to actively provide their students with these opportunities for 
peer support and self-directed learning by creating learning communities with similar interests. In this way, educators can build on the best learning methods already established by successful students.

The most common type of learning community is where two or more courses are linked together by a common theme. The University of Arkansas at Little Rock (UALR) implemented this linked courses method to help students stay in school past the critical first semester when many of them tend to leave (Thompson, 1998).

Assessment indicated a positive result on UALR's first attempt at a learning community involving 25 linked cohort students enrolled in anthropology, rhetoric and writing, and speech courses. On an attitude survey, $88 \%$ of learning community students agreed that it is important to recognize the connections among other course content, and $84 \%$ maintained that the learning community had helped them to see those connections (Thompson, 1998).

The desire to help students recognize the relevance of their education and the connections that exist across discipline boundaries is a driving force in linking courses (Fitch \& Kirby, 2000). Fitch and Kirby describe this as the "content-skill' binary" and show the importance of linking content courses such as American National Government with skill courses such as English Composition. This interdisciplinary linking of courses allows students to think about issues from the different perspectives of the communities in which they are involved. For instance, writing instruction that occurs outside the English Department and in a specific discipline attempts to teach students how to talk and write about that particular body of knowledge and, therefore, access that community (O'Connor and Ruchala, 1998). This concept is similar to the present study in which an Introductory Business Administration course was linked to both a freshman English course and an Oral Communications course. In fact, it is imperative that business students gain the ability to consider issues from a variety of community perspectives because business applications are so broad that graduates can find themselves working in literally any field (O’Connor and Ruchala, 1998).

Another style of cohort courses involves linking a content course with a first-year seminar course for entering freshmen. Indiana University Purdue University Indianapolis (IUPUI) has used this method and found that in all semesters except the first one, seminar participants were retained by a significantly higher percentage. Data collected on grades at the end of the fall 1997 semester showed that seminar participants also earned a higher percentage of high grades than non-participants who were also new to IUPUI (Dick, 1998).

Studies have also pointed out other academic and social benefits of creating learning communities through linked courses. For instance, linked students as part of an organized learning community program achieved increased numbers of completed credits and somewhat higher grade point averages (GPA) (Eanes \& Tutchings, 1990; Luvaas-Briggs, 1984) than their unlinked counterparts. In other studies, linked students were found to have increased GPA and greater retention rates (Sorensen, 1988; Tinto, Goodsell-Love, \& Russo, 1993). Additional research found linkages associated with better performance on a content course exam and self-expressed confidence in using skills from the program (Gammill, Hansen, \& Tinkler, 1992); and increased open-mindedness and confidence in composition skills (Spear, Liff, Hunt, \& Jarvis, 1990). Other positive finding comparing linked with unlinked students included increased interaction between students and faculty and among students as well as increased student intellectual development, retention, and motivation (Smith, 1991); and enhanced understanding of the relevance of and relationships among different subjects (Dunn, 1993; Wishnet, 1991). Most authors concur that the most important benefit of the linked-course model is the establishment of a social and academic support system, allowing students to get to know one another and, in some instances, their instructors, better than they might have otherwise (Tinto \& Goodsell, 1993; Tinto, Goodsell-Love, \& Russo, 1993).

George Mason University Linked states on its web-site that "linked courses will help you to find a community of people who know who you are and who care about what you think. They will also help you make connections between important ideas across different fields of study. Linked courses will help you find your feet at George Mason, both socially and intellectually" (George Mason University, 2000). If, in fact, social success is a primary benefit of linked courses, then one would expect an increase in college retention of students who have participated in such links. Finally, Leonard (1996) notes that linked courses not only provide the students 
participating in them with an increased opportunity for peer collaboration, but that they also provide an opportunity to utilize peer advisors to expose freshmen to successful upperclassmen.

Thus far it appears that much of the data on success rates (GPA in future classes) of students who have participated in linked courses is not statistically significant. However, faculty and students who have participated in linked courses tend to report a stronger sense of understanding and appreciation for the material covered (Wilcox \& delMas, 1997).

\section{The Present Study}

\section{The Origin}

As part of an American Assembly of Collegiate Schools of Business (AACSB) reaccredidation review, the College of Business at California State University Chico (CSUC) revised its undergraduate core curriculum. The major change in the curriculum revision was to institute a freshman level activity based learning Introduction to Global Business course. This course is hosted on the College of Business website and can be located at the following web address: http://www.csuchico.edu/acms/BADM_001/. Prior to the change, the college never offered a business course at the freshman level. Students' first and only exposure to business prior to advancing to the upper division had previously been a two- course sequence in managerial and financial accounting.

The goals of the new course were diverse and can be viewed as attempting to satisfy two important objectives: 1) informed affinity to the study of business, and 2) early preparation in the basic knowledge and skills required for the successful study of business. Informed affinity to the study of business was accomplished by providing students the following opportunities:

1. The opportunity to realistically view and understand the role of business in a global society.

2. The opportunity to understand the undergraduate business curriculum and what knowledge and skills they would possess with a degree in business.

3. The opportunity to understand the difference in majoring in one or another business option (e.g., accounting, marketing, production, etc).

4. The opportunity to understand the types of careers associated with different business foci.

5. The opportunity to interact with an upper division business student mentor assigned to each class section.

6. The opportunity to receive credit for the activity involving attending different college of business student organization meetings (i.e., the e-business club, the human resource management association, etc.).

Early preparation in the basic knowledge and skills required for the successful study of business was accomplished by providing students the following opportunities:

1. Activity based opportunities for mastering the set of basic business software applications required by the college in its business coursework (e.g., internet navigation, Excel database, Powerpoint presentation technology, etc.).

2. Activity based opportunities for interacting and completing group based projects and instruction in teamwork.

3. Opportunities for developing oral communication skills in the preparation and delivery of Powerpoint presentations on business or corporate related topics.

4. Opportunities for developing written communication skills in the preparation of numerous task force reports and an individual book report.

5. Opportunities for developing informational competency through guided instruction in the acquisition of electronic and hard copy business and corporate related information (e.g., corporate home pages, Edgar's On-Line, Morningstar, www.NASDAQ.com, etc.).

6. Introductory level exposure to all the functional areas of business within a global context. 
To complement the new course, the college decided to cross link half of the sections of the freshman Introduction to Global Business course with two other specially designed freshman courses: English Composition and Small Group Communication. These courses were specifically designed to focus on business related issues. All of the reading, writing and informational competency assignments and activities in the English Composition course were focused on international business. Even the course outline and syllabus were co-designed by a co-author and the professor in the Department of English responsible for the freshman composition course. In like manner, the Small Group Communication course focused on workgroups and team leadership within a business context. Each of these other courses fulfilled university general education requirements thus there were no disincentives to students who chose to enroll in the three-course linkage. Enrollment was handled in the following manner. Two sets of 24 students each would enroll in English Composition and Small Group Communication sections and then come together to form one class of forty-eight in the Introduction to Global Business course.

It was anticipated that by creating LCS both the affinity to the study of business and the preparation for the study of business would be enhanced. This new course, its stated objectives, and the enrollment of both LCS and non-LCS formed the basis for the present study.

\section{The Sample}

The sample for the present study consists of two groups - a control group and an experimental group. Students in both groups were asked to sign informed consent documents to give the co-authors permission to track the academic progress of their career so long as they remained business majors at CSUC. The experimental group consisted of 88 (out of 97) students who signed the consent documents and who were enrolled in two sections of the co-author's (a Professor of Management) Introduction to Global Business course in fall 1999. These students were first semester freshman and were part of the linked cohort program. The control group consisted of 49 (out of 120) first semester freshman enrolled in five other sections of Introduction to Global Business in fall 1999. These sections were taught by three faculty members; one was a Professor of Accounting, and the others were full-time Lecturers in Management. Due to catalogue considerations, non-freshman were also enrolled in these non-cohort linked sections. The 120 (potential) first semester freshman in the control group represented approximately 50\% of the enrollment in these sections. The remainder of the students were sophomores and juniors. Although nonconfirmed, it is believed that the higher response rate of students giving informed consent in the co-author's sections was due to student familiarity and trust that the co-author would only use the information for the stated purpose. The author was, for all intent and purpose, unknown to the students in the control group. It is not unexpected therefore that the percent of students giving informed consent to track their academic progress would be lower when compared with the experimental group.

\section{The Hypotheses}

The study investigates two hypotheses comparing the experimental group with the control group:

1. The experimental group will exhibit a higher rate of retention in the study of business than the control group.

2. The experimental group will exhibit higher performance in the study of business (as measured by GPA in the lower division core business courses) than the control group.

Results

The results presented are somewhat tentative since not all students have completed the lower division core business courses. Normal progression would require four semesters for students to complete all lower division courses, core business courses, and general education requirements before declaring a business major in the junior year. Even though four semesters (fall 1999 through spring 2001) have elapsed since the study began, some students still have not completed the aforementioned courses. However, it is natural to expect some students might start taking upper division courses before they have finished the lower division core. 
Hypothesis (1)

At this time, there is statistical evidence that hypothesis (1) is true. The ultimate measure of hypothesis (1) will be business graduation rates, which will not be available for at least two years. For now we consider the percent of students who, after two years, remain business majors. For the experimental group, $75.0 \%$ (66/88) of the students are still business majors, whereas only $57.1 \%$ (28/49) of students in the control group are currently business majors. This difference of $17.9 \%$ is statistically significant at the .0154 level and so we can conclude that the retention rate of students in the experimental group is greater than that of the control group. These results are summarized in Table 1.

Table 1: Statistics for Preliminary Analysis without SAT Covariates

\begin{tabular}{|l|c|c|c|c|c|}
\hline Characteristic & Linked & $\begin{array}{c}\text { Non- } \\
\text { Linked }\end{array}$ & $\begin{array}{c}\text { Difference: } \\
\text { Link- Non-L }\end{array}$ & p-value & Conclusion \\
\hline$\%$ still majoring in business & 75.0 & 57.1 & 17.9 & .0154 (1-tail) & Linked \% higher \\
\hline $\begin{array}{l}\% \text { who have completed at least 4 core } \\
\text { courses }\end{array}$ & 50.0 & 40.8 & 9.2 & .1509 (1-tail) & $\begin{array}{c}\text { No significant } \\
\text { difference }\end{array}$ \\
\hline $\begin{array}{l}\text { Mean GPA per lower division core course } \\
\text { Mean GPA per student (for students who } \\
\text { have completed at least 4 core course) }\end{array}$ & 2.489 & 2.810 & -.321 & .0001 (2-tail) & $\begin{array}{c}\text { Non-Linked has } \\
\text { higher GPA }\end{array}$ \\
\hline Mean SAT Math & 522.0 & 520.7 & 1.3 & .9164 (2-tail) & $\begin{array}{c}\text { No significant } \\
\text { difference } \\
\text { difference }\end{array}$ \\
\hline Mean SAT Verbal & 493.5 & 496.5 & -3.1 & .8163 (2-tail) & $\begin{array}{c}\text { No significant } \\
\text { difference }\end{array}$ \\
\hline Mean SAT Total & 1015.4 & 1017.2 & -1.8 & .9343 (2-tail) & $\begin{array}{c}\text { No significant } \\
\text { difference }\end{array}$ \\
\hline
\end{tabular}

Since, as mentioned above, not all business students have completed the lower division core, we look at retention in business with another measure-percent of students who have completed at least 4 of the required 6 lower division core business courses beyond BADM 001. For the experimental group, 50\% (44/88) of students have completed at least 4 of these lower division core course, whereas for the control group the percent is only $40.8 \%$ (20/49). Even though the percent for the experimental group is $9.2 \%$ larger than for the control group, this result is not statistically significant ( $\mathrm{p}$-value $=.1509)$. See Table 1 for a summary of these results.

At this point it is difficult to make a cause and effect statements about hypotheses (1). That is, we would not conclude that the cohort link class is the cause of the higher retention rate. First of all, students were not randomly assigned to the two groups, but rather each student chose which section of the course in which to enroll, subject to the constraints of the registration process. Some students may have known about the linked cohort nature of some of the sections, and some may not have known. So it is possible that students in the experimental group could have some characteristics that could, at least partially, account for any statistical difference between the two groups. Or, these characteristics could mask any difference between the two groups.

One such characteristic might be academic ability of the students, which could be measured by SAT score. We have the SAT scores for 124 of the 137 students involved in this study (13 students had not taken the SAT), and we can look at hypothesis (1) from the same two points of view as mentioned above, this time taking the SAT scores into consideration. That is, we use the SAT as a covariate, which allows us to compare groups after the data are "adjusted" for differences associated with the SAT scores of the two groups. See Table 2 for the sample sizes. 
Table 2: Sample Sizes

\begin{tabular}{|c|c|c|c|}
\hline Number of Students & All & Linked & Non-Linked \\
\hline Used in preliminary analysis & 137 & 88 & 49 \\
\hline With no SAT & 13 & 7 & 6 \\
\hline Used in revised analysis with SAT covariates, Hypothesis (1) & 124 & $\underline{81}$ & $\underline{43}$ \\
\hline Who haven't completed at least one lower division core course & $\overline{10}$ & $\overline{6}$ & $\overline{6}$ \\
\hline Used in revised analysis with SAT covariates, Hypothesis (2) & 114 & 76 & 38 \\
\hline
\end{tabular}

With regard to the percent of students who, after two years, remain business majors, the analysis changes very little when we include the SAT scores. If we use the SAT total as a covariate (adjust the data for differences in SAT scores), we estimate that the percent of students in the cohort linked group (experimental group) who remain business majors is $20.9 \%$ higher than for students in the non-cohort linked group (control group). This difference is statistically significant at the .0069 level. If we use SAT verbal and math scores as covariates, the estimated difference in percentages is $20.5 \%$, which is statistically significant at the .0077 level. Recall that in the original analysis, the percentage difference between the two groups was $17.9 \%$, with a p-value of .0154. We therefore repeat our hypothesis (1) conclusion from above: the retention rate of students in the experimental group is greater than that of the control group. These results are summarized in Table 3.

Table 3: Regressions for Predicting Business Major Retention Rate

\section{Regression 1, using SAT total as a covariate:}

Major $=\beta_{0}+\beta_{1}$ Group $+\beta_{2}$ Total

$\mathrm{n}=124$

$\mathrm{R}^{2}=.051$

$\mathrm{p}$-value $=.0413$

\begin{tabular}{|l|c|c|c|}
\hline Independent Variable & Coefficient & t-statistic & p-value (2-tail) \\
\hline Intercept & .375 & 1.027 & .3063 \\
\hline Group & .209 & 2.497 & $(1-$ tail) .0069 \\
\hline Total & .000 & .576 & .5654 \\
\hline
\end{tabular}

Regression 2, using SAT math and verbal as covariates:

Major $=\beta_{0}+\beta_{1}$ Group $+\beta_{2}$ Math $+\beta_{3}$ Verbal

$\mathrm{n}=124$

$\mathrm{R}^{2}=.077$

$\mathrm{p}$-value $=.0213$

\begin{tabular}{|l|c|c|c|}
\hline Independent Variable & Coefficient & t-statistic & p-value (2-tail) \\
\hline Intercept & .293 & .805 & .4221 \\
\hline Group & .205 & 2.467 & $(1$-tail) .0077 \\
\hline Math & .001 & 1.883 & .0621 \\
\hline Verbal & -.001 & -1.226 & .2226 \\
\hline
\end{tabular}

Major $1=$ still business major; $0=$ not business major

Group $1=$ linked ; $0=$ non-linked

Total SAT total score

Math SAT math score

Verbal SAT verbal score

Similarly, there is no significant change when we look at percentage of students who have completed at least 4 of the 6 lower division core business courses required beyond BADM 001. Using SAT total as a covariate, we estimate that the percentage of students in the experimental group who have completed at least 4 of the required 6 lower division core business courses to be $10.2 \%$ higher than the corresponding percentage for the control group. This difference is not statistically significant ( $\mathrm{p}$-value $=.1356$ ). Similarly, using SAT verbal and math scores as 
covariates, the estimated difference in percentages is $9.6 \%$, which is not statistically significant (p-value $=.1461$ ). The percentage difference and p-value from the above analysis without using the SAT covariates were $9.2 \%$ and .1509 , respectively. So, as above, even though the percentage completion of core courses is larger for the experimental group, (about 10\% larger), the difference is not statistically significant. See Table 4.

Table 4: Regressions for Predicting Proportion of Students Completing At Least 4 Lower Division Core Courses

Regression 1, using SAT total as a covariate:

Pass $4=\beta_{0}+\beta_{1}$ Group $+\beta_{2}$ Total

$\mathrm{n}=124$

$\mathrm{R}^{2}=.069$

$\mathrm{p}$-value $=.0135$

\begin{tabular}{|l|c|c|c|}
\hline Independent Variable & Coefficient & t-statistic & p-value (2-tail) \\
\hline Intercept & -.680 & -1.693 & .0930 \\
\hline Group & .102 & 1.105 & $(1-$ tail) .1356 \\
\hline Total & .001 & 2.785 & .0062 \\
\hline
\end{tabular}

Regression 2, using SAT math and verbal as covariates:

Pass $4=\beta_{0}+\beta_{1}$ Group $+\beta_{2}$ Math $+\beta_{3}$ Verbal

$\mathrm{n}=124$

$\mathrm{R}^{2}=.107$

$\mathrm{p}$-value $=.003$

\begin{tabular}{|l|c|c|c|}
\hline Independent Variable & Coefficient & t-statistic & p-value (2-tail) \\
\hline Intercept & -.790 & -1.987 & .0492 \\
\hline Group & .096 & 1.058 & $(1$-tail) .1462 \\
\hline Math & .003 & 3.396 & .0009 \\
\hline Verbal & -.000 & -.366 & .7152 \\
\hline
\end{tabular}

Pass $4 \quad 1=$ have passed at least 4 lower division core courses; $0=$ have not passed 4 courses

Group $1=$ linked; $0=$ non-linked

Total SAT total score

Math SAT math score

Verbal SAT verbal score

Hypothesis (2)

We do not have statistical evidence that Hypothesis (2) is true. In fact, the experimental group's mean GPA for completed lower division core business courses is lower than the mean for the control group. This is true if we look at GPA per course-2.49 for the experimental group compared to 2.81 for the control group - and also if we look at GPA per student-2.35 for the experimental group and 2.63 for the control group, or a difference of 28 .

As with hypothesis (1), we can use SAT score as a covariate to try to get a clearer picture. First we eliminate those students in the study who did not complete any of the lower division core, which reduces the overall sample size from 124 to 114 . Using SAT total as a covariate, we estimate that the GPA per student in the experimental group to be .26 grade points lower than for the control group. Using SAT verbal and math as covariates, the experimental group GPA per student is .26 lower than the control group. As above, we can not conclude that the experimental group GPA is larger than the control group GPA. These results are shown in Table 5. 
Table 5: Regressions for Predicting GPA

$\underline{\text { Regression 1, using SAT total as a covariate: }}$

GPA $=\beta_{0}+\beta_{1}$ Group $+\beta_{2}$ Total

$\mathrm{n}=114$

$\mathrm{R}^{2}=.087$

$\mathrm{p}$-value $=.0065$

\begin{tabular}{|l|c|c|c|}
\hline Independent Variable & Coefficient & t-statistic & p-value (2-tail) \\
\hline Intercept & .481 & .625 & .5332 \\
\hline Group & -.265 & -1.493 & $(1-$ tail) .9308 \\
\hline Total & .002 & 2.837 & .0054 \\
\hline
\end{tabular}

Regression 2, using SAT math and verbal as covariates:

GPA $=\beta_{0}+\beta_{1}$ Group $+\beta_{2}$ Math $+\beta_{3}$ Verbal

$\mathrm{n}=114$

$\mathrm{R}^{2}=.091$

$\mathrm{p}$-value $=.0143$

\begin{tabular}{|l|c|c|c|}
\hline Independent Variable & Coefficient & t-statistic & p-value (2-tail) \\
\hline Intercept & .405 & .521 & .6035 \\
\hline Group & -.263 & -1.498 & $(1-$ tail) .9315 \\
\hline Math & .003 & 2.063 & .0415 \\
\hline Verbal & -.002 & -.740 & .4607 \\
\hline
\end{tabular}

GPA GPA per student in lower division core business courses

Group $1=$ linked; $0=$ non-linked

Total SAT total score

Math SAT math score

Verbal SAT verbal score

If we briefly look at the SAT scores, it is not surprising that inclusion of SAT scores into the analysis does not materially change the results. The SAT scores of the two groups are very similar and certainly are not statistically different (see Table 1). Further, there is no correlation between a student's SAT score and whether or not that student continues to be a business major.

One possible criticism of using SAT as covariates is that 13 students in the study did not take the SAT, and these 13 students might somehow be different from those students who did take the SAT. If this is the case, then eliminating the 13 students from the analysis might materially change the results. However, if we repeat the original analysis without covariates, but using only the 124 students who took the SAT, the results are virtually identical to the results using all 137 students. So we are confident that we did not lose significant information when we eliminated those 13 students.

\section{Limitations}

At this point it is difficult to make any cause and effect statements about hypotheses (1). That is, we would not conclude that the cohort link class is the cause of the higher retention rate. First of all, students were not randomly assigned to the two groups, but rather each student chose which section of the course in which to enroll, subject to the constraints of the registration process. Some students may have known about the linked cohort nature of some of the sections, and some may not have known. So it is possible that students in the experimental group could have some characteristics other than SAT scores that could, at least partially, account for any statistical difference between the two groups. Or, these characteristics could mask any difference between the two groups. For example, it is possible that the students who chose to enroll in the link cohort classes were more certain of their intention to major in business. 


\section{Conclusion}

Although tentative, the results of the study are pointing to some subtle and interesting conclusions. It should be noted that the lower division core courses are highly skewed toward quantitative and analytical skill courses. These include finite mathematics, macro and micro economics, business statistics, as well as financial and managerial accounting. These tentative results may be discovering that the peer support networks which the cohort linked students establish work to encourage them to continue the study of business even when their performance in such quantitative and analytical classes is less than they feel comfortable with. In the absence of such peer support, it may be that students more often discontinue the study of business when they do not perform in such classes up to their expectations.

If these results holdup over the entire duration of the study (two years of lower division classes plus an additional 2 years until graduation), there are positive implications for a greater balance of student interest in business majors and options. To the extent that cohort links result in a greater number of less quantitative oriented students pursuing the study of business, it is possible this will result in more students majoring in more qualitative areas of business such as human resource management, marketing and general management. This will not only support better balance within colleges of business but also provide corporate America with the diverse talent, knowledge and skill sets it requires in order to continue to grow and prosper.

\section{Suggestions for Future Research}

The experiment describe here is clearly observational, since the students themselves chose which group they were in: the linked (experimental) or the non-linked (control). It would be very instructive to conduct a designed experiment, one in which the students would be randomly assigned to the groups. This would help eliminate bias and strengthen the validity of the conclusions.

It would also be instructive to replicate the experiment in other disciplines, e.g. in an introduction to engineering class, to see if the results here can be generalized to other fields of study.

\section{References}

1. $\quad$ Abercrombie, M.L.J., Anatomy of Judgment, Basic Books, New York, 1960.

2. Dick, R. C., "Fundamentals of Communication and First Year Success Seminar: Perspective from a Faculty Member of Linked Courses," Paper presented at the $84^{\text {th }}$ annual meeting of the National Communication Association, New York, November 19-24, 1998.

3. Dunn, P., "English 101 and Chemistry 101: Examining Texts Through Different Lenses," Paper presented at the annual meeting of College Composition and Communication, San Diego, California, 1993.

4. Eanes, R., \& Tutchings, T., "An Evaluation of a College Developmental Reading Program," Paper presented at the annual meeting of the American Reading Forum, Sarasota, Florida, 1990.

5. Fitch, B. \& Kirby, A., "Students' Assumptions and Professors' Presumptions," College Teaching, Vol. 48, No. 2, p. 47, 2000.

6. Gabelnick, F., MacGregor, J., Matthews, R.S., \& Smith, B.L., "Learning Communities: Creating Connections Among Students, Faculty, and Disciplines," New Directions for Teaching and Learning, Vol. 41, Jossey-Bass, Inc., San Francisco, 1990.

7. Gammill, L., Hansen, C., \& Tinkler, S., "A Method to Reinforce Basic Skills," Journal of Education for Business, Vol. 67, No. 6, p. 358, 1992.

8. George Mason University, web-site: http://links.gmu.edu/info/faq.html, 2000.

9. Horn, S. K., "Ideas in Practice: Extending Collaboration Beyond the Developmental Classroom," Journal of Developmental Education, Winter 1997, Vol. 21, No. 2, p. 26, 1997.

10. Kellogg, K., "Learning Communities," ERIC Clearinghouse on Higher Education, George Washington University, Washington, DC, 1999. 
11. Leonard, J., "Learning Communities: Linking the Basic Course to the Greater University Community," Paper presented at the $82^{\text {nd }}$ Annual Meeting of the Speech Communication Association, San Diego, CA, November 23-26, 1996.

12. Luvass-Briggs, L., "Integrating Basic Skills with College Content Instruction," Journal of Developmental \& Remedial Education, Vol. 7, No. 2, p. 31, 1984.

13. O'Connor, T. J. \& Ruchala, L. V., "A Model for Small-Group Writing Labs in an Accounting Curriculum," Issues in Accounting Education, Vol. 13, No. 1, p. 93, 1998.

14. Smith, B.L., "Taking Structure Seriously: The Learning Community Model," Liberal Education, Vol. 77, No. 2, p. 42, 1991.

15. Sorensen, V.P., "Bibliographic Instruction in a Developmental Studies Program: A Paired Course Approach," Research Strategies, Vol. 6, No. 4, p. 161, 1988.

16. Spear, S., Liff, L., Hunt, A., \& Jarvis, J., "Multicultural literacy: A Context for Composition,” Teaching English in the Two Year College, Vol. 17, No. 4, p. 247, 1990.

17. Thompson, C., "Assessing the Learning Community: Good News for Speech Communication," Paper presented at the $84^{\text {th }}$ Annual Meeting of the National Communication Association, New York, November 21-24, 1998.

18. Tinto, V., \& Goodsell, A., "Freshman Interest Groups and the First Year Experience: Constructing Student Communities in a Large University," Paper presented at the annual meeting of the College Reading and Learning Association, Kansas City, Missouri, 1993.

19. Tinto, V., Goodsell-Love, A., \& Russo, P., "Building Community," Liberal Education, Vol. 79, No. 4, p. 16, 1993.

20. Wilcox, K. J. \& delMas, R. C., "The 'Package Course' Experience and Developmental Education,” Journal of Developmental Education, Vol. 20, No. 3, p. 18, 1997.

21. Wishnet, N., "Team Teaching of English Linked to Basic Content Area Courses at Solano Community College," Paper presented at the annual convention of the Community College League of California, Santa Clara, California, 1991. 